\title{
Estrogenicity determination in carp, Cyprinus carpio: a laboratory and field approach
}

\author{
M. Solé*, M. Castillo, M. J. Lopez de Alda, C. Porte and D. Barceló \\ Environmental Chemistry Department, IIQAB-CSIC, Jordi Girona, 18-26, 08034 Barcelona, Spain
}

\begin{abstract}
In a laboratory experiment, adult male and female carp, Cyrpinus carpio, were intraperitoneally injected with a single dose of $500 \mu \mathrm{g} / \mathrm{kg}$ of $17 \alpha$-ethynylestradiol $\left(E_{2}\right)$ and eight days afterwards, vitellogenin levels were recorded in blood by Western blot analysis. Moreover, effects on the cytochrome P450 monooxygenase system, phase II and antioxidant defense enzymes of the liver were measured. In a field approach, water and carp were simultaneously collected at the vicinity of two sewage treatment works (STWs) for determining the presence of estrogenic compounds such as nonylphenol (NP) and nonylphenol polyethoxylated compounds (NPEOs) as well as the occurrence of natural and sinthetic estrogens. The induction of vitellogenin on the male individuals was used as a reliable indicator of estrogenic exposure.
\end{abstract}

\section{Introduction}

An increasing broad spectrum of compounds is reported to exhibit varying degrees of estrogenicity [1]. Among such compounds, estrogens and progestogens, both natural and synthetic, as well as the nonionic surfactants alkylphenol polyethoxylates (APEs) and their major degradation product, the persistent nonylphenol (NP), deserve particular attention: the steroids for displaying the highest estrogenic capacities and the surfactants because of their massive use. Despite this, estrogenicity of APEs and other "weak-estrogens" is reported several orders of magnitude lower than that of the natural estradiol [2]. Exogeneous estrogenic (e.g.: 17 $\alpha$ ethynyl estradiol, diethylstilbestrol (DES), and mestranol) and progestational (e.g.: levonorgestrel, norethindrone) chemicals are largely used for treatment of certain hormonal disorders (e.g.: menopause), cancers, and in birth-control pills. In the case of the NPEOs, incomplete degradation in the STWs leads to increasing levels of NP, which is more toxic than the parent compound. The natural and synthetic esteroids are excreted mostly in a less active conjugated form, however, deconjugation by microorganisms during water treatment originates the more potent parent compound. Consequently, presence of such derived compounds will be more relevant at the vicinity of the STWs. In fact, first field evidence of sexual abnormalities in wild fish was given in roach (Rutilus rutilus) in the U.K near STWs.

A widely accepted measure of estrogenicity is the determination of vitellogenin (VTG) in male fish plasma [3-4]. VTG is a yolk egg precursor and its synthesis, in female fish, is regulated by estradiol circulating levels in plasma. In male, as a consequence of exposure to substances that mimic the natural estradiol, VTG can also be synthetised but, as a redundant protein in this gender, the diversion of vital proteins or lipids to VTG formation will have adverse consequences. Also, the implications of biochemical changes into physiological performance or even into a population level reinforce the adequacy of VTG as a specific, early warning biomarker of estrogenic exposure. Only a few estudies have used carp as a sentinel species [5-6] but they were selected for our studies because of their abundance in highly polluted waters.

The cytochrome P450 dependent monooxygense system is located in the liver endoplasmic reticulum and plays a key role in the oxidative metabolism of endogenous compounds (e.g.: steroids), as well as a wide range of xenobiotics. The cytochrome P450 system consists of a family of hemoproteins, the cytochrome P450 family and flavoproteins termed $\mathrm{NAD}(\mathrm{P}) \mathrm{H}$ cytochrome $\mathrm{c}$ reductases being the main components. This system is reported to respond to estrogenic compounds in fish in a very selective manner [7-8]. As a component of this system, the isozyme CYP1A or its associated catalytic activity, 7-ethoxyresorufin $O$-deethylase (EROD), have particularly responded to estrogens [9]. Another isozyme, CYP3A, is mainly involved in the $6 \beta$-hydroxylation of the steroid testosterone [10]; although it has a broad substrate specificity. Metabolites resulting from this previous oxidative process (phase I reactions) can be conjugated to larger endogenous molecules such as glutathione and glucuronic acid, which enhance their solubility and consequently, make them more easily excretable. Of these conjugative reactions (phase II), glutathione $S$-transferase (GST) and UDP glucuronosyltransferase (UDPGT) are among the most studied [11]. Moreover, aerobic organisms have evolved defence systems against oxidative damage such as antioxidant scavengers (glutahione, vitamin $\mathrm{C}$, vitamin $\mathrm{E}$, carotenoid pigments), and specific antioxidant enzymes, namely catalase (EC 1.11.1.6), superoxide dismutase (SOD; EC 1.15.1.1) and glutathione peroxidase (GPX; EC 1.11.1.9) which function towards the removal of reactive oxygen 
species and they have been detected in a number of fish species [12].

The aim of the study was to observe the VTG induction capacity of carp after injection with $\mathrm{EE}_{2}$ at environmentally unrealistic conditions, as well as the existence, if any, of biochemical changes linked to that input. This experiment would also provide good controls for a further application in a field study. This consisted of the analysis of xenoestrogens in two tributaries of the Llobregat river by the use of advanced analytical methods like solid phase extraction followed by liquid chromatography-mass spectrometry (LCMS). Chemicals presence was related to the increase in VTG in the natural fish populations inhabiting these waters.

\section{Experimental section}

\section{Laboratory study}

Adult male and female carp, Cyprinus carpio, were supplied in February 1999 by a fish farm located in the Ebro Delta and kept under controlled conditions as described in [13]. From ten individually identified carp, $250 \mu$ of blood was taken from the caudal vein using an heparinised syringe (VTG control). Afterwards, they were immediately injected with a single intraperitoneal dose of $500 \mu \mathrm{g} / \mathrm{Kg} \mathrm{EE}_{2}$ and returned to a separate tank for the 8 days. After this period, $500 \mu \mathrm{l}$ of blood was collected (VTG induced) with heparinised syringes. After each extraction, blood was immediately centrifuged at $1,000 \mathrm{~g} \times 10 \mathrm{~min}$ and the corresponding plasma frozen to $-80^{\circ} \mathrm{C}$ for VTG analysis. For other biochemical measurements, in addition to the $\mathrm{EE}_{2}$ injected fish, 5 carps were treated via an intraperitoneal injection with the carrier (methanol:corn oil) and another 5 were not injected as they would be used as controls. Animals were killed, measured and sexed. Their livers were immediately dissected and frozen at $-80{ }^{\circ} \mathrm{C}$ for cytochrome $\mathrm{P} 450$ monooxygenase system, transferases and antioxidant enzyme analysis.

\section{Vitellogenin analysis}

An equivalent amount of protein of control and $\mathrm{EE}_{2}$ injected carp was boiled for 5 min in SDS-PAGE sample buffer [14] and afterwards loaded into a $7.5 \%$ polyacrylamide gels topped with $4 \%$ polyacrylamide stacking gels. However, due to the high VTG response in induced fish, for VTG semi-quantitation the amount of protein loaded per lane was $50 \mu \mathrm{g}$ for control carps and $0.5 \mu \mathrm{g}$ in $\mathrm{EE}_{2}$ induced fish. Semiquantitation was carried out using a Quantity One package program from BioRad and expressed as optical density units of the peak area per $\mathrm{mg}$ of protein. Immunoblotting was performed using a 1:1000 dilution rabbit anti-salmon vitellogenin polyclonal antiserum, AA-1 (Biosense Laboratories AS) as described in [13].

\section{Biochemical measurements}

Cytosolic and microsomal fractions were prepared essentially as described in Förlin and Anderson [15]. Cytochrome P450 system components, namely NAD(P)H cytochrome c reductase, total cytochrome $\mathrm{P} 450$ and EROD activity, were measured in the microsomal fraction as described elsewhere [13].

\section{Immunobloting}

For CYP1A and CYP3A protein determinations, $50 \mu \mathrm{g}$ and $25 \mu \mathrm{g}$ of liver microsomal proteins, respectively, were loaded on a $5 \%$ stacking gel and separated on $10 \%$ SDS-polyacrylamide gels as described for VTG analysis. Rabbit antifish CYP1A Polyclonal IgG-fraction, BN-1 (Biosense Laboratories AS) and rabbit-anti trout CYP3A Ab (kind gift from Prof. M. Celander from Göteborg University) were used as primary antibodies for CYP1A and CYP3A determinations, respectively.

\section{Phase II enzymes}

Glutathione S-transferase (GST) activity was measured in the cytosolic fraction and Uridinediphosphate glucuronyltransferase (UDPGT) was measured in the microsomal fraction.

\section{Antioxidant enzymes}

Antioxidant enzymes were measured essentially as described in Livingstone et al. [16]. A more detailed description of phase II and the antioxidants: catalase, SOD and GPX activity measurements are given elsewhere [13].

Protein content was determined by the method of Lowry et al. [17].

\section{Statistics}

One-way ANOVA was performed using Sigmastat program. A Bonferroni's method was used and when $p<0.05$, considered significant.

\section{Field study}

\section{Water and fish collection}

Between April and June 1999, water samples from the influent and effluent from selected STWs were collected as 24-h composite samples. STW Piera, STW Calaf and STW Igualada discharge into the Anoia tributary and STW Manresa discharges into the Cardener tributary. Water samples were also taken at the river stretches where fish were collected (Fig. 1). Adult carp, Cyprinus carpio, were fished by DC electric pulse. At least ten individuals were collected per site and approximately $1 \mathrm{~mL}$ of blood was taken from the caudal vein using an heparinised syringe and $1 \mathrm{mM}$ PMSF (phenylmethylsulphonyl fluoride) was added to the blood to avoid proteolisis. After the extractions, blood was immediately centrifuged at $1,000 \mathrm{~g} \times 10 \mathrm{~min}$ and the corresponding plasma frozen to $-80{ }^{\circ} \mathrm{C}$ for VTG analysis. 


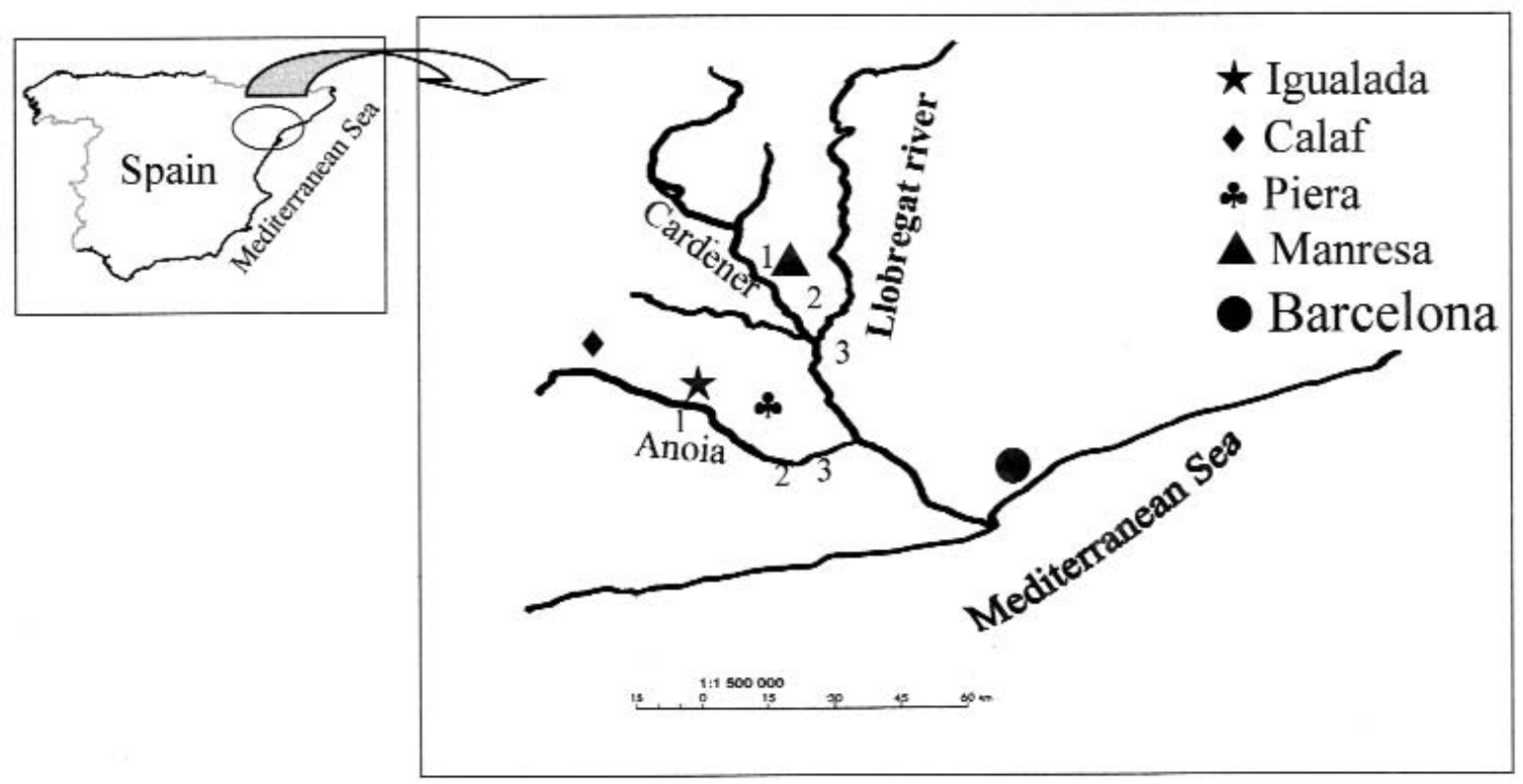

Figure 1. Map indicating where water and fish samples were collected. $\star$ STP Calaf, $\star$ STP Piera, $\star$ STP Igualada and A STP Manresa.

\section{Chemical analysis}

\section{Alkylphenol polyethoxylated and nonylphenol analysis}

The wastewater samples were filtered with a $0.45 \mu \mathrm{m}$ membrane filter and allowed to equilibrate at room temperature before extraction. The experiment was performed using an automated sampler processor ASPEC XL (Automated Sample Preparation with Extraction Columns) from Gilson (Villiers-le-Bel, France). A more detailed description of the method is described elsewhere [18]. Solid-phase extraction (SPE) of the filtered samples was performed with an octadecylsilica (C18) sorbent, LiChrolut RP-18 (500 mg, $6 \mathrm{~mL}$ ), from Merck (Darmstadt, Germany). Identification and quantification of nonylphenol derivatives was performed by liquid chromatography-atmospheric pressure chemical ionization-mass spectrometry (LC-APCI-MS) using a VG Platform system from Micromass (Manchester, UK)

\section{Estrogens and progestogens analysis}

A more detailed description of the method development and validation is described elsewhere [19]. Briefly, filtered samples were extracted with octadecylsilica cartridges LiChrolut RP-18 from Merck, and subsequently analysed by liquid chromatography-diode array detection-mass spectrometry (LC-DAD-MS) using two different interfaces: electrospray (ESP) for estrogens and APCI for progestogens.

\section{Vitellogenin Analysis}

Plasma protein content was determined by the method of Lowry et al. [17] and an equivalent amount of protein was boiled for $5 \mathrm{~min}$ in SDS-PAGE sample buffer [14] and after- wards loaded into a $7.5 \%$ polyacrylamide gels topped with $4 \%$ polyacrylamide stacking gels. The amount of protein loaded per lane was $50 \mu \mathrm{g}$ for the field samples and $0.5 \mu \mathrm{g}$ for the $\mathrm{EE}_{2}$ induced carp used as control.

\section{Immunoblotting}

Proteins which were separated on the SDS-polyacrylamide gels as described for the laboratory exposure experiment. However, these membranes were probed using 1:1000 dilution rabbit koi-carp vitellogenin polyclonal antiserum, (Odense University, Denmark). Western blots were semiquantitated by scanning with a densitometer PhosphoImager (Bio-Rad). Relative quantities of VTG were determined as peak areas of the bands from molecular weight ranging from 70 to $200 \mathrm{kDa}$ due to the appearence of several degradation bands in the field samples. Results expressed as a percentage of the protein content of a sample of an $\mathrm{EE}_{2}$ injected male. Male carp negative control which showed, by western blot, not to display VTG using several polyclonal antibodies (AA-1, OP-1 from Biosense laboratories) was also used as reference.

\section{Results and discussion}

\section{Laboratory experiment}

\section{Vitellogenin analysis}

Immunoblotting with anti-salmon AA-1 polyclonal antibody detected three bands in $\mathrm{EE}_{2}$ induced animals. A thin band of 
approximately $190 \mathrm{kDa}$, a second, wide one of $150 \mathrm{kDa}$ and another thin one of $130 \mathrm{kDa}$. Control males showed no bands and in prespawning females only a very faint one of $150 \mathrm{kDa}$ was evidenced, therefore, the band corresponding to $150 \mathrm{KDa}$ was selected for immunoquantitation. Plasma VTG showed a strong response after $\mathrm{EE}_{2}$ injection in both male and female carp (Fig. 2). Due to the magnitude of the response, a 100-fold dilution of the plasma was required in order to obtain a quantifiable signal by densitometry in the induced animals. Circulating VTG levels reached in treated animals were similar in males and females, but as control levels were lower in males, the increase observed for this gender was higher (90-fold) than the observed in females (67-fold). Total plasmatic protein did not significantly increased in induced animals respect to the control group despite the strong VTG induction. The fact that total plasmatic protein do not reflect the VTG increase could be due to other proteins decreasing and masking the VTG increment. However, in other fish species, total plasmatic protein was reported to increase after 8 days of treatment with $17 \beta$ estradiol $\left(\mathrm{E}_{2}\right)$ at a dose of $0.5 \mathrm{mg} / \mathrm{kg}$ [20]. Strong differences on VTG response have been observed among different species. Thus, VTG response in carp $(C$. carpio) is reported to be much lower than in trout (Salmo trutta) [21]. Another comparative study carried out with male rainbow trout (Oncorhynchus mykiss) and the cyprinid roach (Rutilus rutilus) indicated that exposure at the same $\mathrm{E}_{2}$ dose, circulating VTG levels in trout exceed 30 times those of the roach [22].

\section{Cytochrome P450 system}

CYP1A immunodetermined protein and EROD activity were significantly depleted in $\mathrm{EE}_{2}$ treated animals, with a stronger inhibition $(81 \%)$ observed for the catalitic probe. This is probably due to the use of an anti-salmon polyclonal $\mathrm{Ab}$ which may not be so appropriate for carp. Conversely, administration of nonylphenol (NP) or $\mathrm{E}_{2}$ in juvenile salmon indicated a stronger reduction of CYP1A than EROD activity [23]. A weak cross-reactivity between rabbit anti-fish CYP1A polyclonal IgG-fraction and carp CYP1A protein was demonstrated by western blot. Blots displayed an intense band of about $56 \mathrm{kDa}$ in the $\beta$-NF treated trout (used as positive control); in carp, this band was, if present, at approximately $53 \mathrm{kDa}$ and was very faint in carrier and control carp while was not present in $\mathrm{EE}_{2}$ injected fish. Immunodetermination of CYP3A protein was carried out with anti-trout $\mathrm{P} 450$ con $\mathrm{IgG}$ as the primary $\mathrm{Ab}$, (Gift from M. Celander), and the antibody cross-reacted well with carp liver microsomes in the present study, although no significant differences between the control, carrier and $\mathrm{EE}_{2}$ groups were observed. Two bands of around $50 \mathrm{kDa}$ were obtained in carp whereas only a single band was observed in $\beta-\mathrm{NF}$ treated trout, used as control. Similarly to our findings, killfish (Fundulus heterocitus) and winter flounder (Pleuronectes americanus), have both displayed two molecular weight cross-reactive bands [24]. This suggests that multiple CYP3A proteins may exist in some teleost fish species. Also, the fact that they are expressed at significant

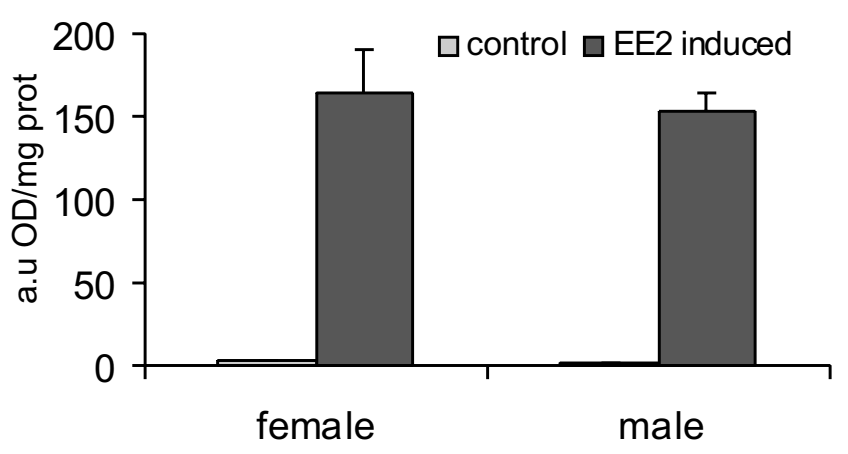

Figure 2. Induction of the vitellogenin (VTG) response in female $(n=2)$ and male $(n=2)$ carp, Cyrpinus carpio, after experimental injection with a single dose of $500 \mu \mathrm{g} / \mathrm{kg} 17 \alpha$-ethynylestradiol $\left(E_{2}\right)$. Only the $150 \mathrm{KDa}$ band was measured by Western blot.

levels in control animals indicates that CYP3A is constitutively expressed and that they may have important endogenous functions in these animals.

Total cytochrome P450 and P420 levels were determined in the liver microsomal fraction, but they did not indicate any significant response after $\mathrm{EE}_{2}$ treatment. Nevertheless, an indication of degradation was observed by higher P420 levels in $\mathrm{EE}_{2}$ treated animals and carrier in comparison to controls. The flavoprotein, NADPH cytochrome (P450) reductase fluctuated similarly to total P450 content but reached statistical significance in $\mathrm{EE}_{2}$ treated and carrier fish in comparison to control fish. No particular trend was observed for NADH cytochrome $\left(b_{5}\right)$ reductase. The fact that carrier and $\mathrm{EE}_{2}$ injected fish responded in an opposite way to each other in cytochrome P450 content and its associated reductase activity suggests that $\mathrm{EE}_{2}$ effects are diminished by the carrier. The masking effect occurs in a more selective manner towards total $\mathrm{P} 450$ content than to the flavoprotein. Alterations in cytochrome $\mathrm{P} 450$ components and activities after $E_{2}$ exposure have been observed in several fish species in the past. Total P450 content and flavoprotein reductases were significantly reduced in brook trout (S. fontinalis) after repeated administration of $3 \mathrm{mg} / \mathrm{Kg} \mathrm{E}_{2}$ doses [7].

\section{Phase II enzymes}

The liver microsomal conjugative enzyme activity UDPGT indicated a decrease after injection with the carrier, which was more accentuated after $\mathrm{EE}_{2}$ injection, although differences among groups were not significant. Similarly, Arukwe et al. [23] reported a certain decrease in UDPGT after $\mathrm{E}_{2}$ administration and after different doses of the "weaker estrogen" nonylphenol (NP). No clear $\mathrm{EE}_{2}$ related response was observed in cytosolic GST either. Depletion in GST activity was observed in carrier fish and increase in $\mathrm{EE}_{2}$ injected individuals (similarly to P450 content and its flavoprotein reductase variations). Nevertheless, induction of cytosolic GST activity (determined using CDNB as substrate), might 
be less relevant than the induction of certain GST isozymes, as it happens for total cytochrome P450 levels. Induction of transferases is seen to fluctuate similarly to the cytochrome P450 system; as the metabolites resulting from the oxidative process are the ones that will be further conjugated and excreted.

\section{Antioxidant enzymes}

Total GPX activity decreased in carrier fish and slightly increased in $\mathrm{EE}_{2}$ treated animals indicating a non clear response to $\mathrm{EE}_{2}$ treatment. A similar behaviour between total GPX and the phase II GST activity was observed, this should be expected considering that total GPX measures the activity of certain GST isozymes and Se-GPX. Other antioxidant enzymes, such as Se-GPX, catalase and SOD, progressively decreased in carrier and $\mathrm{EE}_{2}$ injected fish, although this decrease did not reach significance in comparison to control. On the contrary, a decrease on the redox cycling processes caused by estrogen-mimicking compounds, mainly expressed as a selective EROD inhibition, could reduce the amount of oxyradical species originated as biproducts of this process and therefore reduce the response in the antioxidant defences.

\section{Field study}

\section{Chemical analysis}

High levels of NPEOs and NP in the influent and effluent were determined in the four STWs studied. NP concentration increased in the effluent indicating that this degradation product occurs during STW works. NP levels reached up to the $\mathrm{mg} / \mathrm{L}$ range in the STWs and from non detected to $12.87 \mathrm{mg} / \mathrm{L}$ in the receiving waters. In sewage treated effluents, major nonylphenolic compounds are nonylphenols (NP) indicating that transformation products are much more resistant to microbial degradation. NP values were higher than the recently reported in the influent of the Igualada STW [25], in Europe [26-28] or in the USA [29].

Natural and synthetic estrogens were by far less abundant. Of the various compounds investigated (estradiol, estriol, estrone, ethinyl estradiol, mestranol, diethylstilbestrol, progesterone, norethindrone and levonorgestrel), only estriol and diethylstilbestrol were found at quantifiable concentrations. Estriol was observed to be present in the raw influent of two STWs, Igualada and Piera, but not in the corresponding effluents, thus indicating good treatment efficiency. Diethylstilbestrol, on the other hand, was found in the influent of one of the STWs under investigation (Calaf), and in the effluent of another STW (Piera). Such low levels are in agreement with those published by other authors in similar types of water, which estimate the presence of both natural and synthetic estrogens and progestogens in the ng per liter range [22,30-31] and only in punctual occasions in the $\mu \mathrm{g} / \mathrm{L}$ range [32]. Nevertheless, the limited number of positive results together with the low concentrations obtained, difficults the establishment of possible relationships between the water content of estrogens and progestogens and the estrogenic activity measured as a function of vitellogenin induction in carp.

\section{Vitellogenin induction}

The biological implications of exposure to high amounts of xenoestrogens (mainly NP) was reflected by the presence of plasma VTG in male carp (C. carpio). Only male were selected for the study since, at the time of the year this study was conducted, most of the females were gravid and VTG response was, in this case, biological and would not indicate xenoestrogens exposure. Male carp collected upstream and in two sites further downstream a major STW had increased VTG levels in comparison to a negative male control. Figure 3 indicates that the increase in VTG was more evident in site 2, situated after the nearer STW. Also certain correlation was found between NP present in water and VTG response $(r=0.75)$. Observations were similar for the two Llobregat tributaries but, whereas in the Cardener effluent VTG increase was significant in all sites in comparison to the control, in the Anoia river the same trend did not reach statistical significance. It must be pointed out that the distance from the STW is greater in the Anoia river because attemps to collect fish nearer the plant were unsuccessful. However, despite the distance, NP levels were still significantly high.

Not many field studies simultaneously report on xenoestrogens presence and biological effects in fish. A recent study [31] reported that levels of natural estrogens in the range of tens $n g / L$ and the synthetic estrogen $\mathrm{EE}_{2}$ in the low range of ng/L in UK waters, this levels could be responsible for the estrogenicity of most of the effluents studied [22]. In Sweden, estrogenicity of natural streams was also detected and, in this case, it was attributed to the fact that $\mathrm{EE}_{2}$ exceed by 45 times the value reported to be estrogenic to rainbow trout [30]. The in vivo estimated concentration of NP responsible of vitellogenin induction in rainbow trout is between 1 and $10 \mu \mathrm{g} / \mathrm{L}$ [22,33], for $\mathrm{EE}_{2}$ and $\mathrm{E}_{2}$ it is 1,000 times lower [21,22]. Although cyprinids are less

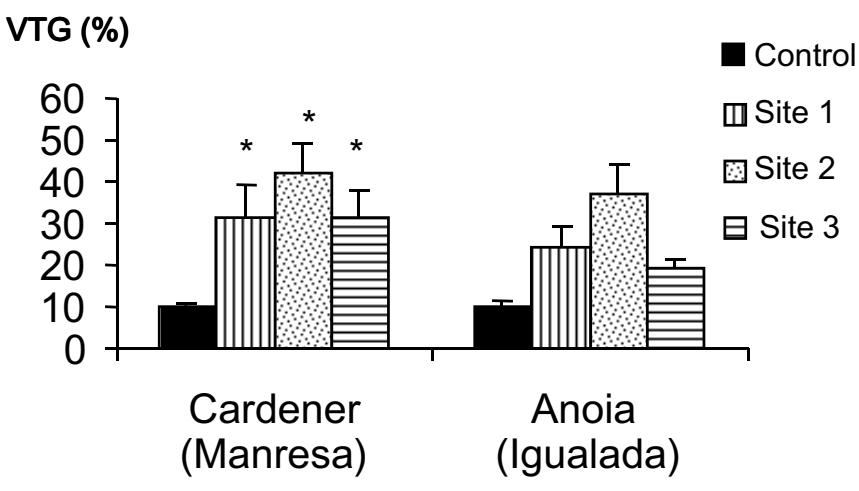

Figure 3. VTG induction, measured by western blot, in male carp sampled in three sites from two Llobregat river tributaries (NE Spain). 
sensitive to xenoestrogens, levels reached in our waters (mainly as NP concerns) amply surpass this threshold and therefore, estrogenicity is likely to occur in many stretches of our rivers. In carp, the most sensitive period to APs is at its early life stages, prior and during sexual differentiation, when a female oviduct has been described to develop in males [34]. This labile period usually coincides with the time of the year when circulating river water is minimal and therefore pollutants are more concentrated.

\section{Conclusion}

$\mathrm{EE}_{2}$ injection of carp caused a very significant and similar induction on VTG in both males and females. Some other biochemical responses such as EROD activity and CYP1A1 were significantly depleted in the $\mathrm{EE}_{2}$ injected fish. In the field an increase in VTG was observed in male fish, mainly at the stations nearer the STW.

\section{Acknowledgements}

The EU projects of the Waste Water Cluster: PRISTINE (ENV4-CT97-0494), SANDRINE (ENV4-CT98-0801) and OWWA (ENV4-CT97-0608) and the Spanish project CICYT (AMB99-0167-CE) are acknowledged for their financial support.

\section{References}

1. McLachlan, J. A. Estrogens in the Environment. II. Influences of Development. New York: Elsevier Science, 1985.

2. Soto, A. M.; Lin, T.; Justicia, H.; Silvia, R. M.; Sonnenschein, C. Chemically Induced Alterations in Sexual and Functional Development: The Wildlife/Human Connection; Colburn, T. and Clement, C., Eds., Princetown, NJ, Princetown Scientific Publishing, 1992, p 295.

3. Sumpter, J. P.; Jobling, S. Environ. Health Prespect. 1995, 103, 173-178.

4. Heppell, S. A.; Denslow, N. D.; Folmar, L. C.; Sullivan, C. V. Environ. Health Prespect. 1995, 103, 9-15.

5. Folmar, L. C.; Denslow, N. D.; Rao, V.; Chow, M.; Crain, D. A.; Enblom, J.; Marcino, J.; Guillette, Jr. L. J. Environ. Health Prespect. 1996, 104, 1096-1101.

6. Goodbred, S. L.; Gillion, R. J.; Gross, T. S.; Denslow, N. D; Bryant, W. L.; Schoeb, T. R. U.S. Geological Survey OpenFile Report, 1996, 96-627.

7. Pajor, A. M.; Stegeman, J. J.; Thomas, P.; Woodin, B. R. J. Exp. Zool. 1990, 253, 51-60.

8. Snowberger, E. A.; Woodin, B. R.; Stegeman, J. J. J. Exp. Zool. 1991, 259, 330-342.

9. Stegeman, J.J.; Hahn, M.E. In: Malins, D.C.; Ostrander, G. K. (Eds) Aquatic toxicology: molecular, biochemical, and cellu- lar perspectives; Boca Raton, FL: Lewis Publishers, 1994, pp 87-204.

10. Waxman, D. J.; Attisano, C.; Geungerich, F. P.; Lapenson, D. P. Arch. Biochem. Biophys. 1988, 263, 424-436.

11. George, S. G. In: Malins, D.; Ostrander, G. (Eds) Aquatic Toxicology: Molecular biochemical and cellular perspectives; Boca Raton, FL: Lewis Publishers, 1994, pp 37-85.

12. Lemaire, P.; Livingstone, D. R. Trends Comp. Biochem. Physiol. 1993, 1, 1119-1150.

13. Solé, M.; Porte, C.; Barceló, D. Arch. Environ. Contam. Toxicol. 2000, 38 (4), 494-500.

14. Laemmli, U. K. Nature 1970, 22, 680-685.

15. Förlin, L.; Anderson, T. Comp Biochem Physiol. 1985, 80B, 569-572.

16. Livingstone, D. R.; Archibald, S.; Chipman, J. K.; Marsh, J. W. Mar. Ecol. Prog. Ser. 1992, 91, 97-104.

17. Lowry, O. H.; Rosebrough, N. J.; Farr, A. L.; Randall, R. J. J. Biol. Chem. 1951, 193, 265-275.

18. Castillo, M.; Alonso, M. C.; Riu, J.; Barceló, D. Environ. Sci. Technol. 1999, 33, 1300-1306.

19. López de Alda, M. J.; Barceló, D. J. Chromatogr. A 2000, 892, 391-406.

20. Mañanós, E.; Zanuy, A.; Le Menn, F.; Carrillo, M; Núñez, J. Comp. Biochem. Physiol. 1994, 107B, 205-216.

21. Purdom, C. E.; Hardiman, P. A.; Bye, V. J.; Eno, N. C.; Tyler, C. R.; Sumpter, J. P. Chemistry and Ecology 1994, 8, 275-285.

22. Routledge, E. J.; Sheahan, D. A.; Desbrow, C.; Brighty, E. J.; Waldock, M.; Sumpter, J. Environ. Sci. Technol. 1998, 32, 1559-1565.

23. Arukwe, A.; Förlin, L.; Goksøyr, A. Environ. Tox. Chem. 1997, 16, 2576-2583.

24. Celander, M.; Buhler, D. R.; Förlin, L.; Goksøyr, A.; Miranda, C. L.; Woodin, B. R.; Stegeman, J. J. Fish Physiol. Biochem. 1996, 15, 323-332.

25. Castillo, M; Barceló, D. Anal. Chem. 1999, 71, 3769-3776.

26. Blackburn, M .A.; Waldock, M. J. Wat. Res. 1995, 29, 16231629.

27. Lye, C. M.; Frid, C. L. J.; Gill, M. E.; Cooper, D. W.; Jones, D. M. Environ. Sci. Technol. 1999, 33, 1009-1014.

28. Ahel, M.; Giger, W.; Schaffner, C. Wat. Res. 1994, 28, 11431152.

29. Naylor, C. G.; Mieure, J. P.; Adams, W. J.; Weeks, J. A.; Castaldi, J. F.; Ogle, L. D.; Romano, R. R. J. Am. Oil Chem. Soc. 1992, 69, 695-703.

30. Larsson, D. G. J.; Adolfsson-Erici, M.; Parkkonen, J.; Pettersson, M.; Berg, A. H.; Olsson, P. E.; Förlin, L. Aquat. Toxicol. 1999, 45, 91-97.

31. Desbrow, C.; Routledge, E. J.; Brighty, G. C.; Sumpter, J. P.; Waldock, M. Environ. Sci Technol. 1998, 32, 1549-1558.

32. Ternes, T. A.; Stumpf, M.; Mueller, J.; Haberer, K.; Wilken, R. D.; Servos, M., Sci. Total Environ. 1999, 225, 81-90.

33. Jobling, S.; Sheahan, D.; Osborne, J. A.; Matthiessen, P.; Sumpter, J. P. Environ. Toxicol Chem. 1996, 15, 194-202.

34. Gimeno, S.; Komen, H.; Venderbosch, P. W. M.; Bowmer, T. Environ. Sci. Technol. 1997, 31, 2884-2889. 